\title{
Voorkeurstrategieë in die Noord-Sotho-vertaling van Terminologie van het tolken
}

\author{
Eleanor Cornelius \\ Departement Tale, Kultuurstudies en Toegepaste Linguistiek, Universiteit van Johannesburg, Suid-Afrika \\ E-pos: eleanorc@uj.ac.za
}

Marné Pienaar

Departement Tale, Kultuurstudies en Toegepaste Linguistiek, Universiteit van Johannesburg, Suid-Afrika E-pos: mpienaar@uj.ac.za

\begin{abstract}
Cornelius and Pienaar (2017) point out that there is a need for standardised interpreting terminology in South Africa, not only in the indigenous languages, but also in English and Afrikaans. In order to bridge this gap and to contribute to the standardisation of interpreting terminology, these authors decided to translate the 2008 publication by Salaets, Segers and Bloemen, with the Dutch title Terminologie van het tolken, published by Vantitlt in Nijmegen, in Afrikaans and in English, and to provide translation equivalents of the terms in one Nguni (Zulu) and one Sotho language (Northern Sotho). The original Dutch was adapted accordingly. The title of this multilingual product is Interpreting terminology / Terminologie van het tolken / Tolkterminologie / Mareo a botoloki / Amatemu okutolika (Pienaar \& Cornelius 2018).
\end{abstract}

The first phase of the project is reported in Cornelius and Pienaar (2017), consisting of the following actions: (1) expanding the original lemma list to include interpreting terms with high frequency of use in South Africa, whilst at the same time also limiting the original lemma list to only those terms that are in use and relevant in a South African context, (2) translating the dictionary articles into Afrikaans and English, (3) localising the content for the South African user, including the additional comments and examples, and (4) adapting the original Dutch to reflect resulting localised content.

In this article the focus is on the second phase of the project, namely the provision of translation equivalents in Zulu and Northern Sotho. Finding translation equivalents in Northern Sotho proved to be particularly difficult. In contrast to standardised languages such as English and Afrikaans, the lack of a Northern Sotho standard variety forced the translators who collaborated on the project to act mainly as terminologists, and not translators, as they were continuously confronted with problems relating to zero equivalence (lexical/linguistic gaps). Despite similarities and overlap, translation and terminology represent different knowledge domains. Problems translators grapple with can of course be terminological in nature, for instance when 
confronted with instances of lexical or linguistic gaps, where the target language lacks a translation equivalent for a source language term.

Different approaches to terminography can be followed (Alberts 2017). In order to assist with the standardising of interpreting terminology, whilst also contributing to language development in Zulu and Northern Sotho, the traditional subject-oriented methodology was preferred in Interpreting terminology. This approach focuses on the concept, and the relationship between concepts and conceptual systems. Standardised terms and concepts enable effective communication and knowledge transfer in a particular domain. This approach typically involves eleven steps. In this article we demonstrate how the decision to include translation equivalents in Northern Sotho, in particular, resulted in some disruption of the steps and the order in which the steps were executed, and we highlight some of the stumbling blocks the Northern Sotho translators had to contend with. These translators resorted to a number of strategies to solve these problems, including generalisation, paraphrasing and borrowing.

Keywords: subject-oriented approach, lexical gap, standardisation, generalisation, paraphrasing, borrowing, Northern Sotho

\section{Inleiding}

Cornelius en Pienaar (2017:181-182) verwys na die uitgebreide navorsing oor verskillende aspekte van tolking wat gedurende die afgelope dekade in Suid-Afrika onderneem is (sien Le Roux (2007), Wittezaële (2008), Bothma en Verhoef (2008), Verhoef en Du Plessis (2008), Olivier (2008) Verhoef (2009), Verhoef en Blaauw (2009), Verhoef (2010), Saulse (2010), Dose (2010), Clausen (2011), Brewis (2012, 2014), Lesch (2014), Makhubu (2011), Ralarala (2012 en 2014), Feinauer en Lesch (2013), Molefe (2015), Anyele (2015), Pienaar en Cornelius (2015), Mathey (2017) en Du Plessis (2017)). Hulle argumenteer dat, alhoewel daar klaarblyklik tans baie navorsing oor tolking in Suid-Afrika gedoen word, tolkterminologie in Suid-Afrika nog nie formeel en volledig in alle plaaslike tale gestandaardiseer is nie. Onpresiese, vae en dubbelsinnige kommunikasie in hierdie hoogs gespesialiseerde kennisdomein is die ongelukkige, en onnodige, gevolg hiervan wat aanleiding gee tot verwarring en frustrasie.

Dit is teen hierdie agtergrond dat Cornelius en Pienaar besluit het om Terminologie van het tolken deur Salaets, Segers en Bloemen, wat in 2008 by Vantilt in Nijmegen verskyn het, vir die Suid-Afrikaanse gebruiker te vertaal en te lokaliseer. Dié oorspronklike Nederlandse naslaanwerk wat in totaal 204 bladsye beslaan, bevat 'n lys van 174 tolkterme. Elke term word in Nederlands omskryf en in sommige gevalle word bykomende, verhelderende inligting in die vorm van, onder andere, opmerkings en voorbeelde gegee. Daarna volg vertaalekwivalente in vyf Europese tale.

Nadat Terminologie van het tolken gelokaliseer en in Afrikaans en Engels vertaal is, is vertaalekwivalente in Noord-Sotho en Zulu bygevoeg (sien Cornelius en Pienaar (2017)). 'n Tipiese inskrywing in die uiteindelike plaaslike produk met die titel Interpreting terminology / Terminologie van het tolken / Tolkterminologie / Mareo a botoloki / Amatemu okutolika, ${ }^{1}$ wat

\footnotetext{
${ }^{1}$ Ter wille van ruimtebesparing word die titel in hierdie artikel voortaan verkort na Tolkterminologie.
} 
in 2018 deur African Sun Media uitgegee is, word vervolgens aangebied. Etikette (byvoorbeeld definisie, opmerking, voorbeeld, antonieme/sinonieme, kruisverwysings, ens.) word verskaf, wat aandui hoe elke inskrywing gestruktureer is:

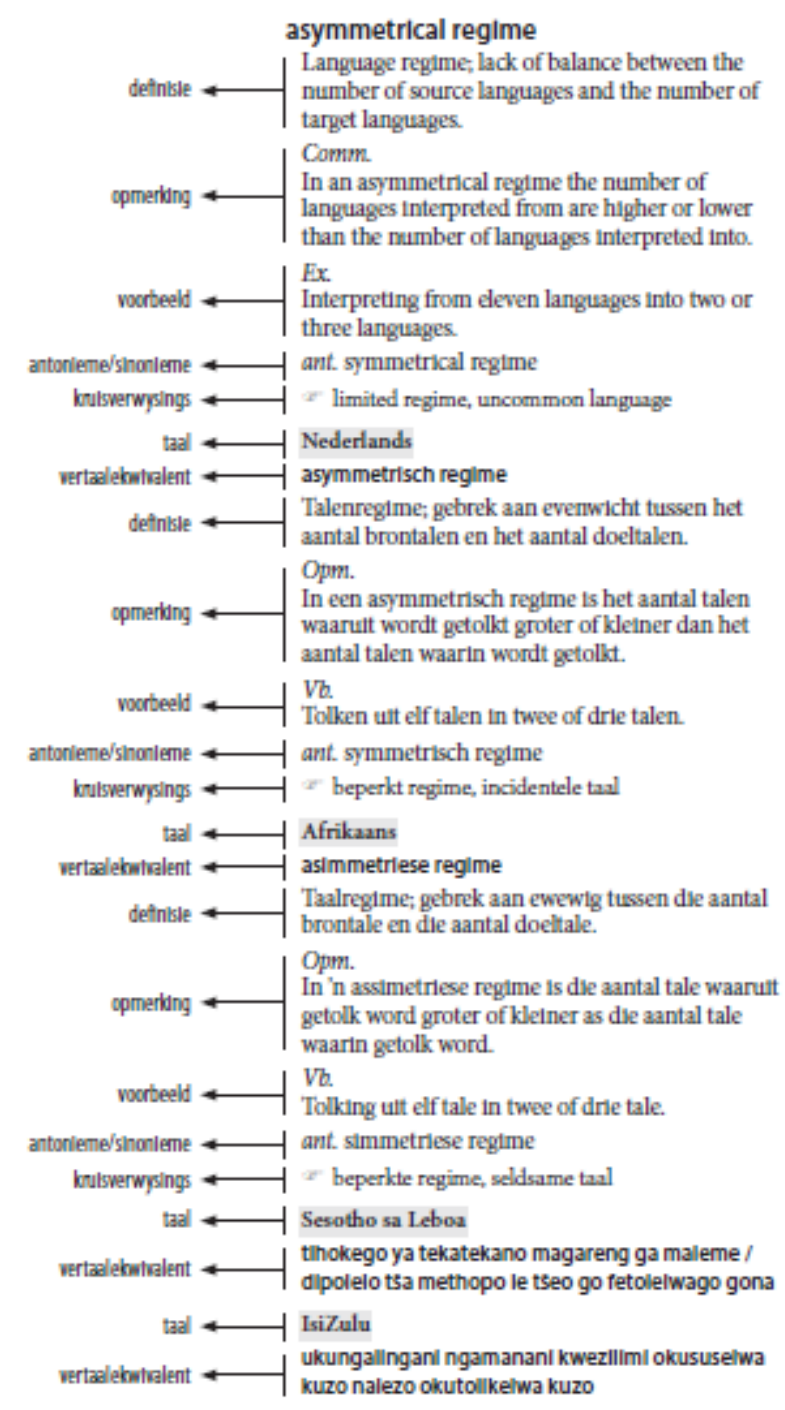

Figuur 1: 'n Tipiese inskrywing in die plaaslike naslaanbron

Cornelius en Pienaar (2017) gee 'n uiteensetting van die lokaliserings- en vertaalprosedures wat tydens die vertaling van die bronteks in Afrikaans en in Engels gevolg is. Dit is gedoen met die bedoeling van Zgusta, soos aangehaal deur Gouws (2017:434), in gedagte waar hy oor die verskyning van Manual of Lexicography (1971) opmerk dat hy die boek as 'n sukses sal beskou indien dit net in één aspek slaag, naamlik om die opstellers van leksikografiese produkte en woordeboeke te oorreed om beskrywings of besprekings van hulle metodes en die benaderings tot hulle spesifieke probleme, maar ook hulle oplossings, beskikbaar te stel binne die meer algemene raamwerk van taalteorie en nie om net hulle teoretiese resultate so onopsigtelik moontlik in hulle woordeboeke te inkorporeer nie. Hierdie artikel streef dieselfde doel na, maar fokus in die besonder op die probleme, en strategieë vir die oplossing daarvan, wat verband hou met die voorsiening van vertaalekwivalente in Noord-Sotho. 


\section{Die insluiting van vertaalekwivalente in Noord-Sotho}

Die gebrek aan gestandaardiseerde terminologie in die Afrikatale word allerweë bekla en dikwels ook voorgehou as rede waarom onderwys en opleiding nie in dié tale kan plaasvind nie (sien Prah 2007; Sibula 2007; Ouane en Glanz 2010:14; Alberts 2017:115). Onderrig en leer, deur middel van 'n spesifieke taal, kan slegs geskied indien terminologie bestaan wat uiteindelik gestandaardiseer word (Alberts 2017:302). Dit is juis ook Alberts (2017:51) wat spesifiek verwys na die rol wat terminologie in die verwerwing van kennis speel en die frustrasie wat in professionele kontekste ervaar word wanneer struikelblokke in die kommunikasieproses ontstaan as 'n regstreekse gevolg van 'n gebrek aan gestandaardiseerde terminologie.

Aangesien die samestellers en skrywers van hierdie artikel al twee (1) by die Universiteit van Johannesburg werksaam is, (2) betrokke is by die opleiding van tolke, vertalers en teksredigeerders en (3) ook self praktiserende SAVI-geakkrediteerde tolke is, het hulle onderneem om 'n bydrae te lewer tot die ontwikkeling van die Afrikatale deur ook vertaalekwivalente in Noord-Sotho en Zulu by te voeg tydens die vertaling en lokalisering van Terminologie van het tolken. Die besluit om hierdie twee tale te betrek, spruit uit die feit dat Noord-Sotho en Zulu, benewens hulle amptelike nasionale taalstatus, ook amptelike tale van die Universiteit van Johannesburg is, naas Afrikaans en Engels.

Nadat die Nederlandse teks gelokaliseer en in Engels en Afrikaans vertaal is, is die vertaalde teks aan twee vertaalspanne gestuur. Twee vertalers in elkeen van die twee Afrikatale (twee vir Zulu en twee vir Noord-Sotho) het elk eers afsonderlik en onafhanklik van mekaar vertaalekwivalente vir die trefwoorde geïdentifiseer. In gevalle waar die twee vertalers met dieselfde vertaalekwivalent na vore gekom het, is daardie betrokke vorm dan aanvaar. In die Noord-Sotho het die vertalings waarmee die twee vertalers onafhanklik van mekaar vorendag gekom het, in die geval van 80 uit 168 terme nie met mekaar ooreengestem nie (dus 47,6\%). Die gebrek aan eenstemmigheid was nie so problematies in die geval van Zulu nie en die vertalers kon deur middel van konsensus besluit wat hulle as die mees gepaste vertaalekwivalent vir die betrokke term beskou. Dit was kennelik nie die geval met die NoordSotho nie.

Een van die redes vir die gebrek aan eenstemmigheid in die Noord-Sotho was dat die vertalers terme moes skep. By gebrek aan bestaande vertaalekwivalente het hulle byvoorbeeld dikwels van parafrasering as vertaalstrategie gebruik gemaak. Dit bied deels 'n verduideliking vir die groot diskrepansie tussen die twee vertalers.

In hierdie opsig eggo die volgende aanhaling van Moropa (2008:168) twee aspekte wat regstreeks met die doel en uiteindelike bydrae van hierdie projek verband hou, naamlik (1) die rol wat vertalers in die ontwikkeling en uiteindelike standaardisering van 'n taal ${ }^{2}(\mathrm{kan})$ speel en

(2) dat betekenistoeganklikheid en begripsvorming voorrang moet geniet bo die keuse van 'n bepaalde variëteit:

\footnotetext{
${ }^{2}$ Volgens Alberts (2017:168-169) is ‘n standaardtaal gekodifiseer, eenvormig en voldoen dit aan basiese beginsels en reëls. Standaardisering behels dat reëls vir grammatika, spelling en skryfwyse bestaan en dat daar voldoende terminologie en woordeboeke is. Dit beteken dat die ontwikkeling van terminologie bydra tot die standaardisering van ' $n$ taal.
} 
In languages of limited diffusion (LLDs), translators make an enormous contribution towards the development of such languages by creating and standardising terms, with the primary aim being to prevent linguistic exclusion. When it is likely that a term may not be understood by a number of readers, the translator must explain the term - a particular variety of language should never be promoted at the expense of the reader's understanding.

Omdat die vertalers nie eenstemmigheid kon bereik nie, is 'n nasiener gevra om die diskrepansies te oorweeg en 'n aanbeveling te maak oor wat die voorkeurvorm tussen twee moontlikhede sou wees. Die eerste nasiener het telkens gemeld dat al twee vorme van 'n voorgestelde vertaalekwivalent moontlik aanvaarbaar kan wees. Aanvaarde terminologiepraktyk vereis egter dat een term vir een konsep in 'n taal gebruik moet word, aangesien sinonieme tot onnodige duplisering, verwarring en uiteindelik gebrekkige kommunikasie kan lei (Alberts 2017:180). Gevolglik is die hulp van 'n tweede nasiener ingeroep, wat aangedui het dat sekere voorgestelde moontlikhede in sy opinie gewoon verkeerd was. Twee vertalers en twee nasieners kon nie konsensus bereik nie. Dit is belangrik om hier te noem dat al twee die oorspronklike vertalers en die twee nasieners professionele vertalers is. Hierdie impasse het daartoe gelei dat die samestellers dit begin oorweeg het om af te sien van die plan om ekwivalente in Noord-Sotho aan te dui. Einde raad is 'n akademikus wat in Noord-Sotho spesialiseer aangestel om die teks na te gaan en ook terugvertalings van die vertaalekwivalente aan die samestellers te voorsien.

Taljard (2008:1074) bespreek die feit dat Noord-Sotho nog nie ten volle gestandaardiseer is nie. Sy maak die volgende opmerking: "In selecting a standard form from amongst multiple candidates, the terminologist therefore needs to make sure that his choice is linguistically and terminologically well-informed, so as to contribute on a general level to the standardization of the Northern Sotho language”. Dit was juis hierdie multiple candidates wat tot groot frustrasie aanleiding gegee het. ' $n$ Voorbeeld hiervan is die taalbenamings vir Engels, Nederlands en Zulu wat deur die Noord-Sotho-vertalers aangegee is as English, Dutch en isiZulu. Die name is gevolglik net so in Noord-Sotho oorgedra. Die eerste nasiener het akkoord gegaan, maar die tweede nasiener het beswaar gemaak en aangedui dat die korrekte benoemings eerder Seisimane, Sedutch en Sezulu is. Dié beswaar is deur die Noord-Sotho-spesialis gehandhaaf en hierdie vorme is in die uiteindelike teks opgeneem.

\section{Die verhouding tussen vertaling en terminologie}

In 'n artikel wat die verband tussen vertaling en terminologie ondersoek, wys Cabré (2010) daarop dat, ondanks bepaalde ooreenkomste en areas van oorvleueling, vertaling en terminologie verskillende kennisdomeine of -terreine verteenwoordig, en dat die twee dissiplines ook verskil wat betref spesifieke doel. Vertaling behels die vertaalprosesse en ontledings van die bron- en doelteks, terwyl terminologie eerder fokus op die linguistiese voorstelling van 'n enkele abstrakte konsep, wat kennis in 'n bepaalde spesialisgebied verteenwoordig. Wat doel betref, is vertaling gemoeid met die uitdrukking van 'n semantiespragmatiese struktuur wat oorspronklik in 'n ander taal geproduseer is; terminologie het ten doel om spesialisterme te versamel wat in glossariums, woordeboeke, termlyste en databasisse opgeneem kan word vir gebruik deur onder andere vertalers. Die verhouding tussen vertaling en terminologie is egter asimmetries. Vertalers wat hulle besig hou met gespesialiseerde vertaling benodig uiteraard terminologie. Terminoloë “oes” terme uit tekste wat deur spesialiste 
geskryf of opgestel is, en wel in werklike kommunikasiesituasies, maar oorspronklike tekste geniet voorkeur - vandaar die asimmetriese verhouding. Slegs in gevalle waar daar geen tekste oor 'n bepaalde onderwerp in 'n bepaalde taal is nie, wend terminoloë hulle na vertalings (Cabré 2010:357).

In sy bespreking oor die verhouding tussen vertaling en terminologie merk ook Sager (2001:258-262) op dat “(t)ranslation and terminology function on two different linguistic and cognitive planes and, as disciplines, focus on different areas of language study”. Volgens hom is vertaling in die eerste plek 'n aktiwiteit wat binne die toegepaste linguistiek val, waar dit veral gaan om die manipulering van tekste. Dit is in die ruimte tussen die bron- en die doelteks waar die vertaler, volgens Chesterman (1997:92), worstel met vertaalprobleme, tentatiewe oplossings vind, aspekte van 'n eerste weergawe hersien, en so meer. In hierdie ruimte kan vertalers natuurlik te kampe hê met probleme wat terminologies van aard is. Dan moet die vertaler in staat wees om die probleem as 'n terminologiese probleem te herken sodat ' $n$ oplossing met behulp van 'n terminologiese metode gevind kan word (Cabré 2010:359). 'n Voorbeeld hiervan is wanneer die vertaler voor 'n geval van zero-ekwivalensie te staan kom, waar die doeltaal nie 'n (gepaste) vertaalekwivalent vir 'n brontaalterm het nie (Alberts 2017:91; Gouws \& Prinsloo 2005:158-160). Dit kom onder andere voor omdat spesialiste nie die betrokke taal gebruik om oor die onderwerp te kommunikeer nie en daar dus nie 'n term daarvoor bestaan nie; of daar bestaan nie 'n gestandaardiseerde term waaroor spesialiste eenstemmigheid bereik het of wat deur 'n normerende liggaam onderskryf word nie (Cabré 2010:360).

Terminologieteorie betrek teoretiese én toegepaste linguistiek en maak dus net deels staat op tekste as bronmateriaal. Terminologieteorie neem abstrakte kognitiewe eenhede, of konsepte, as vertrekpunt om gepaste linguistiese uitdrukkings of terme te identifiseer.

Eenvoudig gestel, kan daar gesê word dat die fokus in vertaling op die linguistiese verteenwoordiging van 'n kognitiewe eenheid geplaas word; die vertaler beweeg van die linguistiese term in die brontaal na die konsep ten einde 'n korresponderende linguistiese realisering in 'n ander taal, die doeltaal, te vind. Daar kan selfs geredeneer kan word dat vertalers net 'n minimale kennis van terminologieteorie nodig het om terme te vind wat korrespondeer met 'n konsep in twee verskillende tale (Cabré 2010:363). Die praktyk is egter meer kompleks: vertalers kom gevalle teë waar konsepte soortgelyk eerder as identies is en hulle moet dan terme in die doeltaal vir nuwe konsepte vind. Sager (2001:259) som die verskil tussen vertaling en terminologie soos volg op: vertalers werk met taal-in-praktyk terwyl terminoloë aspekte van taal-in-gebruik betrek, maar eintlik fokus op taal as 'n abstrakte stelsel.

Uiteraard kan vertalers, afhangende van die tipe vertaling wat ter sprake is, sonder kennis van terminologieteorie vertaal. In die teks ter sprake, was dit nie die geval nie, omdat dit juis gaan om die daarstel van terme in ander tale en hier veral dan in die daarstel van tolkterminologie in Noord-Sotho, 'n taal wat nog nie ten volle gestandaardiseer is nie, en waar daar in vergelyking met 'n ander doeltaal, soos Afrikaans, min bronne (bv. woordeboeke en glossariums) beskikbaar is. Die Noord-Sotho-vertaalspan moes gevolglik ook as terminoloë optree.

Alberts (2017:179) stel dit duidelik dat terminologieskepping en -insameling 'n gespesialiseerde taak is wat toewyding van vakspesialiste, opgeleide terminoloë, taalpraktisyns 
en taalkundiges vereis. Die eindresultaat van die werk lei wel tot die verfyning van vakgebiede, meer presiese kommunikasie en die ontwikkeling van tale.

\section{Benaderings tot die skepping en insameling van terminologie}

In haar bespreking van terminologiebeleid en -bestuur in Suid-Afrika, onderskei Alberts (2017: 177-182) vier benaderings tot terminologie-insameling, te wete vak-, vertaal-, taalgemeenskapen taalbeplanninggerigte benaderings. Die vakgerigte benadering word as die tradisionele wyse beskou waarop terminologie ingesamel word. Dié benadering fokus op konsepte en die verhouding wat daar tussen konsepte en konseptuele stelsels bestaan. Binne hierdie raamwerk word klem geplaas op die standaardisering van terme en konsepte ten einde doeltreffende kommunikasie en kennisoordrag binne 'n professionele gemeenskap te bewerkstellig. In die meeste gevalle is vakkundiges self verantwoordelik vir die dokumentering van gespesialiseerde terminologie. As voorbeeld kan daar na die werksaamhede van die Terminologiekoördineringsafdeling van die Nasionale Taaldiens van die Departement Kuns en Kultuur gekyk word. Hulle werk tipies binne 'n bepaalde konseptuele domein (of vakgebied) en begin gewoonlik met die ekserpering van terme uit 'n bron wat in 'n spesifieke brontaal (in Suid-Afrika is dit gewoonlik Engels) beskikbaar is. Die dokumenteringstaal of brontaal word gewoonlik gebruik om konsepte in te definieer en vertaalekwivalente moet dan in die ander 10 amptelike SuidAfrikaanse tale voorsien word. Die proses is egter nie so eenvoudig as wat dit mag voorkom nie en Alberts (2017:178-179) dui elf stappe aan voordat die proses van terminologieinsameling afgehandel is:

\begin{tabular}{|l|l|}
\hline 1 & Ekserpering uit bronne \\
\hline 3 & Verduideliking van konsepte binne konteks; voorsiening van definisies, voorbeelde en ander tersaaklike inligting \\
\hline 5 & Boorsiening van vertaalekwivalente in die doeltaal/-tale \\
\hline 6 & Samestelling van konseptermlys vir oorweging deur vak- en taalkundiges \\
\hline 7 & Aanpassing van databasis/-bank na aanleiding van terugvoer \\
\hline & Versoek aan amptelike nasionale taalliggame om terme te verifieer \\
\hline 9 & Verandering van die databasis/-bank na aanleiding van aanbevelings van nasionale taalliggame \\
\hline 10 & Publikasie en verspreiding van termlys aan teikengebruikers \\
\hline 11 & Verspreiding van terminologie na eindgebruikers (wat insluit vakspesialiste, taalpraktisyns, gewone \\
\hline
\end{tabular}

Figuur 2: Die elf stappe in die vakgerigte benadering (Alberts 2017)

Die tweede benadering, naamlik die vertaalgerigte benadering tot terminografie, neem 'n brontaal wat vertaal moet word as vertrekpunt. Vertalers wat met gespesialiseerde tekste werk, ervaar toenemend 'n behoefte om terminologiese inligting vas te lê en te ontsluit, aangesien dit tyd bespaar en hulle in staat stel om meer doeltreffend te werk en sodoende hulle produktiwiteit te verhoog. Hierdie benadering stel terminologiese ekwivalente in die onderskeie tale vas wat 
die vertalers as vertrekpunte neem. Vertaalgerigte terminografie is hoogs ontwikkel in geïnstitusionaliseerde tweetalige of meertalige lande en gemeenskappe. Terminologieprosessering word beskou as 'n aktiwiteit wat vertaalwerk ondersteun. Terminologieinsameling word 'n byproduk van die vertaalproses en veeltalige en politematiese termbanke kom tot stand (Alberts 2017:179-180).

In teenstelling met die vertaalgerigte benadering wat met tekste werk, word terminologie in die gemeenskapsgerigte benadering tot terminografie by landelike en stedelike taalgemeenskappe ingesamel en dan gedokumenteer. Nie net vertalers is hierby betrokke nie, maar ook vakspesialiste, akademici en diegene wat bekommerd is oor die moontlike verlies van inheemse kennisstelsels. Die ingesamelde terminologie kan dan aan die Terminologiekoördineringsafdeling van die Nasionale Taaldiens vir dokumentering gestuur word.

Die laaste benadering wat Alberts (2017:181) bespreek, is die taalbeplanninggerigte benadering. Hier val die klem op amptelike ingryping om die status van 'n minderheidstaal te verhoog wat, om welke rede ook al, histories benadeel is. Die onderliggende idee aan hierdie benadering is dat die gebruik van 'n onstabiele taal kan verander wanneer amptelike liggame sistematies en strategies toetree. In sulke gevalle word terminologie wat ingevoer word van tale wat terminologies-ontwikkeld is en in dominante lande gepraat word, vervang deur plaaslike of inheemse ekwivalente. In Suid-Afrika is hierdie vorm van taalbeplanning veral die taak van die Pan-Suid-Afrikaanse Taalraad (PanSAT) se elf Nasionale Taalliggame.

Alberts (2017:182) meen dat die verskillende benaderings tot terminologie nie wedersyds uitsluitend is nie en wel samelopend gebruik kan word. Die benadering wat tydens die samestelling van Tolkterminologie gevolg is, is die vakgerigte benadering. Hierdie benadering is die tradisionele wyse waarvolgens terminologie in Suid-Afrika geoes word. Die klem word geplaas op die standaardisering van terme en konsepte in professionele domeine. Volgens hierdie benadering is vakspesialiste meestal self betrokke (Alberts 2017:177).

\section{Die vakgerigte benadering tot Tolkterminologie}

In terme van die elf stappe wat hierbo genoem is, stem die proses wat met die samestelling van Tolkterminologie gevolg is grootliks ooreen met die vakgerigte benadering, maar dit verskil ook in sekere opsigte.

Omdat Terminologie van het tolken (Salaets, Segers en Bloemen, 2008) as bronteks gebruik is, is die eerste stap, naamlik ekserpering, nie gevolg nie. Dieselfde geld stappe 2 en 3 aangesien die konsepte reeds binne konteks verduidelik is en van definisies, voorbeeldsinne en in sommige gevalle ook van opmerkings, sinonieme/antonieme en kruisverwysings voorsien is (sien figuur 1 in die Inleiding hierbo). Wat egter wel dadelik opgeval het, was dat die Nederlandse/Belgiese konteks aangepas sou moes word om Suid-Afrikaanse omstandighede te weerspieël. Reeds in stap 4 het dit duidelik geword dat dit nodig was om die lemmalys uit te brei om voorsiening te maak vir opvoedkundige tolking soos dit in Suid-Afrika toegepas word. Tweedens het dit gou geblyk dat die voorbeelde en ander inligting (byvoorbeeld die opmerkings) wat ter toeligting aangebied is, gelokaliseer sou moes word vir 'n Suid-Afrikaanse teikengebruiker. Derdens het die bronteks terme bevat wat tersaaklik is in 'n unieke Nederlandse (en Europese) konteks, maar wat nie in Suid-Afrika relevant is of gebruik word nie. Hierdie terme is met groot omsigtigheid geïdentifiseer en uit die doellys weggelaat (sien 
Cornelius en Pienaar, 2017). Dit het daartoe gelei dat stappe 6 en 7, waar 'n konseptermlys saamgestel en aangepas word na aanleiding van terugvoer van vakkundiges, Alberts se stap 5, die voorsiening van vertaalekwivalente vooraf gegaan het. Stap 5 het ook meer as die voorsiening van die vertaalekwivalente behels, aangesien die aanvaarde konseplys volledig met definisies, voorbeeldmateriaal, opmerkings en, waar ter sake, sinonieme, antonieme en kruisverwysings in Afrikaans en toe in Engels vertaal is. Daarna is die bronteks gewysig sodat die Nederlandse lys die veranderde lemmalys weerspieël. Wat stappe 8 en 9 betref, is daar nie van die nasionale taalliggame gebruik gemaak nie, aangesien Nederlands, Afrikaans en Engels reeds gestandaardiseer is. Die bronteks het in elk geval reeds die Engelse vertaalekwivalente bevat. Die Afrikaanse vertaalekwivalente het hier en daar probleme opgelewer aangesien die bronlys 'n aantal vreemdetaalterme (meestal Franse terme, byvoorbeeld décalage en perroquet) bevat wat net so in die Nederlands behou is, maar waarvoor terme in die Afrikaans gevind of geskep moes word om betekenistoeganklikheid te verhoog. In plaas daarvan om die nasionale taalliggame vir Afrikaans te betrek, is die drietalige teks na vertalers, teksredigeerders en vakkundiges gestuur vir verifiëring en terugvoer.

Op hierdie stadium is daar teruggegaan na stap 5 waar die vertaalekwivalente in Zulu en NoordSotho bygevoeg moes word. Omdat stappe 6 en 7 nie meer op hierdie stadium ter sprake was nie, aangesien die konseptermlys reeds vas was, is daar onmiddellik voortgegaan met stappe 8 en 9 waar die vertalings nagesien is. Dit is op hierdie punt waar veral die byvoeging van vertaalekwivalente in Noord-Sotho heelwat probleme opgelewer het, wat verband hou met van die aspekte wat hierbo uitgelig is. Hierdie fase van die proses het stappe 10 en 11, naamlik die publikasie en verspreiding van die terminologielys aan teikengebruikers en aan eindgebruikers (vakspesialiste, taalpraktisyns en burgers) via CD-roms of aanlyn aansienlik vertraag en vervolgens word daar eers daarby stilgestaan.

Die stappe wat in hierdie projek en proses gevolg is, sien soos volg daaruit:

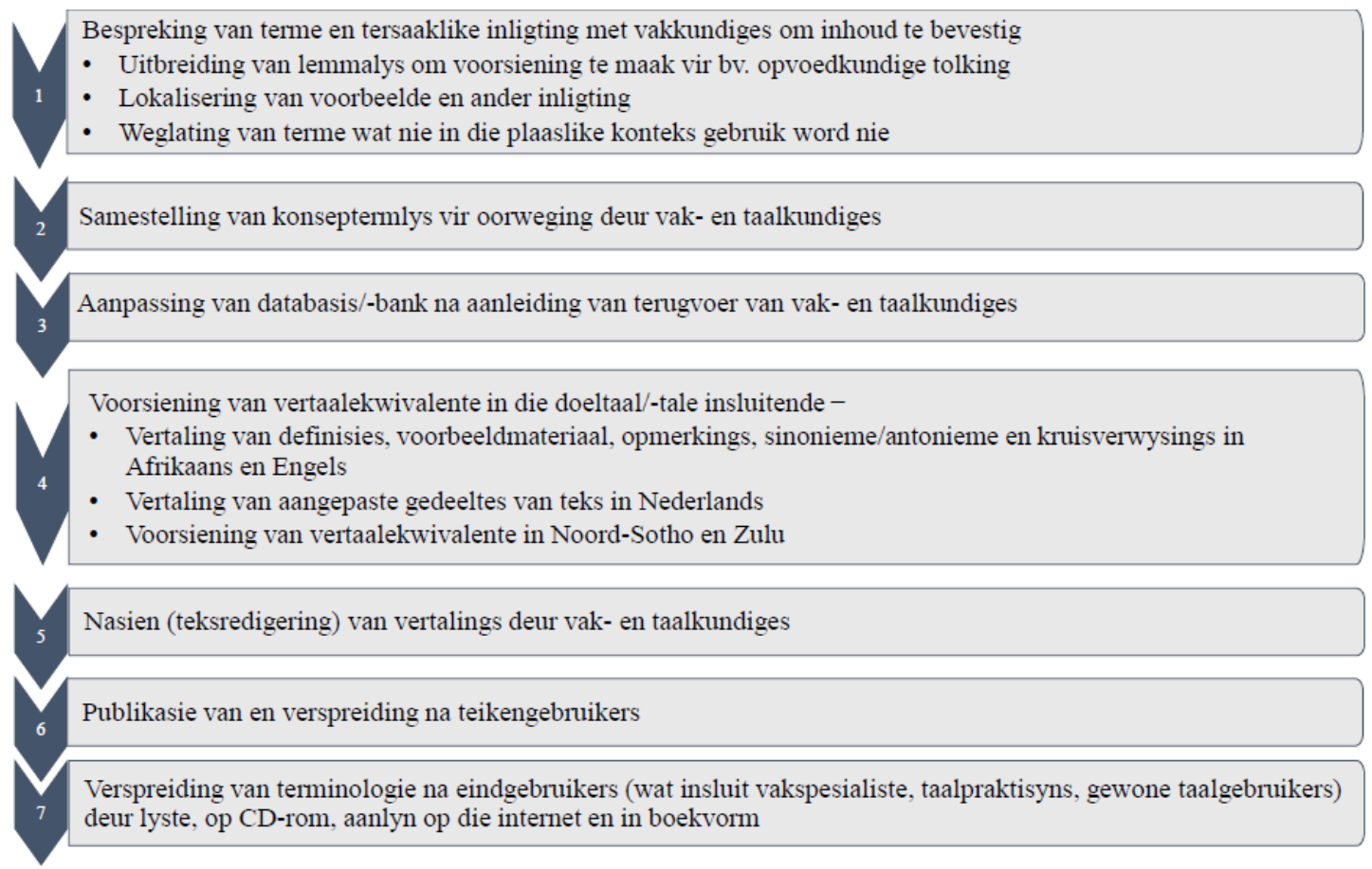

Figuur 3: Stappe gevolg in die vertaling en lokalisering van Tolkterminologie 
Hieruit blyk dat (1) sekere stappe nie nodig was nie (byvoorbeeld ekserpering) of nie uitgevoer is nie (byvoorbeeld skakeling met nasionale taalliggame); en (2) die volgorde waarin die stappe uitgevoer is, nie presies die orde wat Alberts (2017) beskryf, weerspieël nie. Die projek is dus in sewe stappe, soos hierbo beskryf, afgehandel. Die gebrek aan skakeling met nasionale taalliggame van PanSAT, byvoorbeeld dié vir Zulu en Noord-Sotho, regverdig hier 'n kort verduideliking. Gegee die huidige stand van sake by hierdie statutêre liggaam, wat gebuk gaan onder bestuurs- en ander probleme, en die rimpeleffek hiervan wat uitkring na die provinsiale taalkomitees, die nasionale taalliggame en in 'n mindere mate ook die nasionale leksikografieeenhede, het die samestellers besluit om eerder gebruik te maak van (1) SAVI-geakkrediteerde vertalers en/of tolke, of (2) akademici aan Suid-Afrikaanse universiteite wat hulle in hierdie tale as kundiges onderskei het. In beide gevalle het die kundiges uitgebreide kennis van tolking as 'n akademies-teoretiese spesialisgebied en/of ervaring as praktiserende tolke.

\section{Zero-ekwivalensie en die hantering daarvan}

Baker (2011:15 e.v.) bespreek die probleem van zero-ekwivalensie op woordvlak waar daar geen direkte of presiese vertaalekwivalent in die doeltaal nie. Sy lys verskeie redes vir die voorkoms van die verskynsel waaronder die bestaan van kultuurspesifieke konsepte; brontaalkonsepte wat nie in die doeltaal geleksikaliseer is nie; doeltale wat nie oor 'n bepaalde superordinaat of spesifieke term (hiponiem) beskik nie; verskille in fisiese of interpersoonlike perspektiewe, verskille in ekspressiewe betekenis, in vorm of in die frekwensie en doel van die gebruik van sekere vorms; en laastens die gebruik van leenwoorde.

Zero-ekwivalensie kan op verskillende maniere hanteer word en Baker (2011:23-44) stel dit baie duidelik dat daar geen vaste resep is vir die hantering van zero-ekwivalensie nie, maar meld wel die volgende strategieë wat algemeen deur professionele vertalers wat met hierdie probleem gekonfronteer word, gebruik word:

\begin{tabular}{|c|c|c|}
\hline \multicolumn{2}{|c|}{ Strategie } & Voorbeeld $^{3}$ \\
\hline i. & $\begin{array}{l}\text { Die gebruik van 'n kultuurspesifieke } \\
\text { item om die oorspronklike item mee te } \\
\text { vervang. }\end{array}$ & braai in Afrikaans word izoso in Zulu \\
\hline ii. & $\begin{array}{l}\text { Die vertaling vind plaas deur gebruik te } \\
\text { maak van 'n meer algemene woord ('n } \\
\text { superordinaat) }\end{array}$ & melktert word tart in Engels \\
\hline iii. & 'n Meer neutrale woord word gebruik & $\begin{array}{l}\text { boerewors word (farm-style) sausage in } \\
\text { Engels }\end{array}$ \\
\hline iv. & $\begin{array}{l}\text { 'n Suiwer of 'n verinheemsde } \\
\text { leenwoord word gebruik }\end{array}$ & $\begin{array}{l}\text { Suiwer leenwoorde word presies net so in } \\
\text { die doeltaal behou, bv. 'n kultuurspesifieke } \\
\text { item soos pizza, bosberaad of indaba } \\
\text { Wanneer leenwoorde verinheems word, } \\
\text { word die vreemdheid daarvan verander } \\
\text { deur die ortografie van die doeltaal te } \\
\text { gebruik, bv. } \\
\text { - kalk word kalaka in Tswana } \\
\text { - sement word semende in Swati }\end{array}$ \\
\hline
\end{tabular}

\footnotetext{
${ }^{3}$ Voorbeelde kom meestal uit Wallmach en Kruger (1999; 2010), maar ook uit Ndlovu (2006).
} 


\begin{tabular}{|c|l|l|}
\hline v. & $\begin{array}{l}\text { Gebruik 'n leenwoord plus 'n } \\
\text { verduideliking }\end{array}$ & $\begin{array}{l}\text { ・ tender ("om aan te bied”) word } \\
\text { tentere in Suid-Sotho }\end{array}$ \\
\hline vi. & Parafrasering & $\begin{array}{l}\text { Ten einde die doelteksleser op te lei word } \\
\text { sauté in Frans as sauté, of braai effens en } \\
\text { vinnig in Afrikaans vertaal }\end{array}$ \\
\hline vii. & Weglating & $\begin{array}{l}\text { driehoek in Afrikaans word as umfanekiso } \\
\text { ohlangothi zintathu in Zulu vertaal wat } \\
\text { terugvertaal kan word as 'n ontwerp met } \\
\text { drie kante }\end{array}$ \\
\hline viii. & Byvoeging & $\begin{array}{l}\text { Probeer om minder suiker te gebruik om dit } \\
\text { te vermy. Probeer om versoeters in jou tee } \\
\text { en koffie te gebruik word in Zulu vertaal as } \\
\text { Ukuvikela lokhu zama ukusebenzisa isikalo } \\
\text { sikashukela esincane ekhofini nasetiyeni, } \\
\text { wat terugvertal kan word as Om dit te } \\
\text { vermy, probeer 'n klein hoeveelheid suiker } \\
\text { in (jou) koffie en tee te gebruik. }\end{array}$ \\
\hline ix. & Illustrasie & $\begin{array}{l}\text { Bykomende inligting word in die doelteks } \\
\text { gegee om die woord minder dubbelsinnig } \\
\text { te maak of om die implisiete betekenis } \\
\text { duideliker te mak. }\end{array}$ \\
\hline
\end{tabular}

Tabel 1: Vertaalstrategieë vir die hantering van zero-ekwivalensie

\section{Uitdagings en struikelblokke in die Noord-Sotho-vertaling}

'n Informele gesprek met die Noord-Sotho-spesialis het verskeie insigte gebring rakende die redes waarom die oorspronklike Noord-Sotho-vertalers sekere besluite geneem het. Die tabel hieronder gee 'n aanduiding van die tipe probleme wat die Noord-Sotho-vertalers ervaar het. Die eerste kolom gee die term in Afrikaans, Engels en Nederlands. In die tweede kolom verskyn (1) die Noord-Sotho-ekwivalent waarop die aanvanklike vertalers ooreengekom het, met ' $n$ terugvertaling in Engels, maar wat volgens die eerste nasiener steeds problematies was, of (2) terme waaroor die twee aanvanklike vertalers nie konsensus kon bereik nie (sien byvoorbeeld voorbeeld 5 en 6 in die tabel). In die derde kolom verskyn die finale, nagesiene vertaling, soos goedgekeur deur die Noord-Sotho-spesialis, ook met 'n terugvertaling in Engels. ${ }^{5}$

\footnotetext{
${ }^{4}$ Vergelyk Ngobeni (2013: 3) vir 'n uiteensetting van die gebruik van illustrasies in die geval van zeroekwivalensie in Noord-Sotho.

${ }^{5}$ Die terugvertaling word in Engels aangedui aangesien dit so van die Noord-Sotho-spesialis ontvang is en die skrywers van die artikel nie die voorbeeldmateriaal in gedrang wou bring deur 'n Afrikaanse vertaling van die terugvertaling in Engels nie.
} 


\begin{tabular}{|c|c|c|c|}
\hline Nommer & $\begin{array}{l}\text { Afrikaans } \\
\text { Engels } \\
\text { Nederlands }\end{array}$ & $\begin{array}{l}\text { Eerste vertaling met } \\
\text { terugvertaling }\end{array}$ & $\begin{array}{l}\text { Finale vertaling met } \\
\text { terugvertaling }\end{array}$ \\
\hline 1 & $\begin{array}{l}\text { Tolkterminologie } \\
\text { Interpreting } \\
\text { terminology } \\
\text { Terminologie van } \\
\text { het tolken } \\
\text { (Dit is die titel van } \\
\text { die boek.) }\end{array}$ & $\begin{array}{l}\text { Mareo a tlhathollo } \\
\text { Terugvertaling: } \\
\text { Explanation terminology }\end{array}$ & $\begin{array}{l}\text { Mareo a botoloki } \\
\text { Terugvertaling: } \\
\text { Interpreting terminology }\end{array}$ \\
\hline 2 & $\begin{array}{l}\text { A-taal } \\
\text { A language } \\
\text { A-taal }\end{array}$ & $\begin{array}{l}\text { leleme la A / leleme la } \\
\text { tswalo la mofetoledi goba } \\
\text { leleme le lengwe le le } \\
\text { lengwe leo a le tsebago go } \\
\text { swana le leleme la mme. } \\
\text { Terugvertaling: language } \\
\text { A / mother tongue of the } \\
\text { translator or any other } \\
\text { language that he/she knows } \\
\text { like his/her mother tongue }\end{array}$ & $\begin{array}{l}\text { leleme/polelo ya A / } \\
\text { leleme goba polelo ya } \\
\text { mme ya toloki goba } \\
\text { leleme /polelo ye nngwe } \\
\text { le ye nngwe yeo a e } \\
\text { tsebago bjalo ka leleme } \\
\text { goba polelo ya mme } \\
\text { Terugvertaling: } \\
\text { language A / mother } \\
\text { tongue of the interpreter } \\
\text { or any other language } \\
\text { that he/she knows like } \\
\text { his/her mother tongue. }\end{array}$ \\
\hline 3 & $\begin{array}{l}\text { ad hoc-tolk } \\
\text { ad hoc interpreter } \\
\text { ad hoc-tolk }\end{array}$ & $\begin{array}{l}\text { tlhathollo ya nakwana } \\
\text { Terugvertaling: temporary } \\
\text { explanation }\end{array}$ & $\begin{array}{l}\text { go toloka ka ntle le go } \\
\text { hwetša tlhahlo } \\
\text { Terugvertaling: to } \\
\text { interpret without having } \\
\text { training }\end{array}$ \\
\hline 4 & $\begin{array}{l}\text { aktiewe taal } \\
\text { active language } \\
\text { actieve taal }\end{array}$ & $\begin{array}{l}\text { leleme la phetolelo } \\
\text { Terugvertaling: language } \\
\text { of translation }\end{array}$ & $\begin{array}{l}\text { leleme leo toloki e } \\
\text { kgonago go le tolokela / } \\
\text { polelo yeo toloki e } \\
\text { kgonago go e tolokela. } \\
\text { Terugvertaling: } \\
\text { language that an } \\
\text { interpreter is able to } \\
\text { interpreting into }\end{array}$ \\
\hline 5 & $\begin{array}{l}\text { antisipering } \\
\text { anticipation } \\
\text { anticipatie }\end{array}$ & $\begin{array}{l}\text { kamaka/phopholetšo } \\
\text { Terugvertaling: } \\
\text { ponder/feel }\end{array}$ & $\begin{array}{l}\text { kemelo / letetše } \\
\text { Terugvertaling: } \\
\text { anticipate/anticipation }\end{array}$ \\
\hline 6 & $\begin{array}{l}\text { A2-tolk } \\
\text { cheval } \\
\text { cheval }\end{array}$ & $\begin{array}{l}\text { mohlatholliphetelela / } \\
\text { bokgoniphetelela } \\
\text { Terugvertaling: } \\
\text { Explanator*.../ knowledge }\end{array}$ & $\begin{array}{l}\text { toloki ye e ka beiwago } \\
\text { ka diphapošaneng tše } \\
\text { pedi tše di fapanego tša } \\
\text { go toloka } \\
\text { Terugvertaling: an } \\
\text { interpreter that can be } \\
\text { placed in two different } \\
\text { interpreting booths }\end{array}$ \\
\hline
\end{tabular}




\begin{tabular}{|c|c|c|c|}
\hline 7 & $\begin{array}{l}\text { begripsoomblik } \\
\text { déclic } \\
\text { déclic }\end{array}$ & $\begin{array}{l}\text { sebakanyana sa temogo } \\
\text { Terugvertaling: awareness } \\
\text { pause }\end{array}$ & $\begin{array}{l}\text { sebakanyana sa } \\
\text { tshepetšo ya go toloka } \\
\text { Terugvertaling: split } \\
\text { span / pause in the } \\
\text { process of interpreting }\end{array}$ \\
\hline 8 & $\begin{array}{l}\text { digtheid } \\
\text { density } \\
\text { densiteit }\end{array}$ & $\begin{array}{l}\text { teteano } \\
\text { Terugvertaling: density / } \\
\text { shrubbiness }\end{array}$ & $\begin{array}{l}\text { bokaalo bja tshedimošo } \\
\text { bjo bo tšeiwago go seo } \\
\text { se boletšwego } \\
\text { Terugvertaling: the } \\
\text { amount of information } \\
\text { that is processed in what } \\
\text { is being said }\end{array}$ \\
\hline 9 & $\begin{array}{l}\text { draagbare } \\
\text { tolktoerusting } \\
\text { bidule } \\
\text { bidule }\end{array}$ & $\begin{array}{l}\text { setlabakelo sa tlhathollelo sa } \\
\text { go athwa. } \\
\text { Terugvertaling: } \\
\text { explanation equipment that } \\
\text { can be carried or portable. }\end{array}$ & $\begin{array}{l}\text { sedirišwa sa go toloka sa } \\
\text { go athwa. } \\
\text { Terugvertaling: } \\
\text { interpreting equipment } \\
\text { that can be carried } \\
\text { around or that is portable }\end{array}$ \\
\hline 10 & $\begin{array}{l}\text { hokkie } \\
\text { booth } \\
\text { cabine }\end{array}$ & $\begin{array}{l}\text { phapošanabohlathollelo / } \\
\text { boothi } \\
\text { Terugvertaling: } \\
\text { explanation room / booth }\end{array}$ & $\begin{array}{l}\text { Phapošana ya go toloka / } \\
\text { boothi ya go toloka } \\
\text { Terugvertaling: } \\
\text { interpreting room / } \\
\text { interpreting booth }\end{array}$ \\
\hline 11 & $\begin{array}{l}\text { liggaamstaal } \\
\text { body language } \\
\text { lichaamstaal }\end{array}$ & $\begin{array}{l}\text { leleme la tshepetšo ya ditho } \\
\text { Terugvertaling: body } \\
\text { language }\end{array}$ & $\begin{array}{l}\text { leleme ka taetšo ya ditho } \\
\text { tša mmele / polelo ka } \\
\text { taetšo ya ditho tša } \\
\text { mmele. } \\
\text { Terugvertaling: body } \\
\text { language / information is } \\
\text { conveyed through body } \\
\text { movements }\end{array}$ \\
\hline 12 & $\begin{array}{l}\text { skryftolk } \\
\text { audio interpreter } \\
\text { audiotolk }\end{array}$ & $\begin{array}{l}\text { mhlatholli wa Difoa } \\
\text { Terugvertaling: Explanator } \\
\text { for the Deaf }\end{array}$ & $\begin{array}{l}\text { Toloki ka go ngwala } \\
\text { /Toloki ya Difoa / go } \\
\text { toloka ka go ngwala fase } \\
\text { go ngwalela Difoa goba } \\
\text { batho bao ba sa kwego } \\
\text { gabotse. } \\
\text { Terugvertaling: audio } \\
\text { interpreter /interpreting } \\
\text { in a form of writing }\end{array}$ \\
\hline 13 & $\begin{array}{l}\text { sluiting } \\
\text { closing } \\
\text { closing }\end{array}$ & $\begin{array}{l}\text { pheleletšo ka mantšu } \\
\text { Terugvertaling: using } \\
\text { words for completion }\end{array}$ & $\begin{array}{l}\text { mokgwa wa go } \\
\text { itokišetša go toloka } \\
\text { Terugvertaling: } \\
\text { interpreting exercise }\end{array}$ \\
\hline 14 & $\begin{array}{l}\text { tolkhokkie-etiket } \\
\text { booth etiquette } \\
\text { cabine-etiquette }\end{array}$ & $\begin{array}{l}\text { melao ya boothi } \\
\text { Terugvertaling: booth rules }\end{array}$ & $\begin{array}{l}\text { melao ya boothi / melao } \\
\text { ya phapošana } \\
\text { Terugvertaling: booth } \\
\text { rules }\end{array}$ \\
\hline
\end{tabular}




\begin{tabular}{|l|l|l|l|}
\hline 15 & $\begin{array}{l}\text { tolkoefening } \\
\text { interpreting } \\
\text { exercise } \\
\text { tolkoefening }\end{array}$ & $\begin{array}{l}\text { go itlwaetša go hlatholla } \\
\text { Terugvertaling: to get used } \\
\text { to explaining }\end{array}$ & $\begin{array}{l}\text { go itlwaetša go toloka } \\
\text { Terugvertaling: to learn } \\
\text { how to interpret / to } \\
\text { practise how to interpret }\end{array}$ \\
\hline 16 & $\begin{array}{l}\text { tweerigtingtolking } \\
\text { birectional } \\
\text { interpreting } \\
\text { bi-actief tolken }\end{array}$ & $\begin{array}{l}\text { thathollo ya } \\
\text { mathokomabedi } \\
\text { Terugvertaling: Two-sided } \\
\text { explanation. }\end{array}$ & $\begin{array}{l}\text { go toloka ka leleme la A } \\
\text { le go toloka ka leleme la } \\
\text { B / go toloka ka polelo } \\
\text { ya A le go toloka ka } \\
\text { polelo ya B } \\
\text { Terugvertaling: two } \\
\text { way interpreting / } \\
\text { interpreting using } \\
\text { language A and } \\
\text { interpreting using } \\
\text { language B }\end{array}$ \\
\hline 17 & $\begin{array}{l}\text { volgafstand } \\
\text { décalage }\end{array}$ & $\begin{array}{l}\text { sekgala sa nako sa seo se } \\
\text { se boletšwego ka polelo } \\
\text { ya mothopo / leleme la } \\
\text { mothopo le seo se }\end{array}$ \\
& $\begin{array}{l}\text { Terugvertaling: space of } \\
\text { time between languages } \\
\text { fetolelwago ke toloki ya } \\
\text { sammaletee } \\
\text { Terugvertaling: space } \\
\text { of time between what } \\
\text { was said in the source } \\
\text { language and what was } \\
\text { interpreted by the } \\
\text { simultaneous interpreter }\end{array}$ \\
\hline
\end{tabular}

Tabel 2: Terugvertalings in Engels van twee weergawes van die Noord-Sotho

Die terugvertalings in kolomme 2 en 3 gee 'n goeie aanduiding van die vertaalstrategieë wat die vertalers gebruik het. In die bespreking van die vakgerigte benadering tot terminografie vroeër, is daar genoem dat stap 1 gewoonlik ekserpering uit bronne behels. Volgens Alberts (2017:179) beteken dit dat terminograwe brontaalterme uit relevante materiaal, bv. vertaalde tekste, handboeke en vaktydskrifte ekserpeer. In Tolkterminologie is die vertalers met die bronteks gekonfronteer en ná die eerste vertaalrondte was dit duidelik dat daar heelwat onakkurate vertalings in die Noord-Sotho voorgekom het. Voorbeeld 1 (Tolkterminologie) en ook die titel van die boek, is aanvanklik as Mareo a tlhathollo vertaal wat terugvertaal kan word as Explanation terminology. Dit kan beskou word as 'n goeie voorbeeld van Baker se tweede strategie (kyk tabel 1 hierbo) waar 'n meer algemene woord of 'n superordinaat gebruik is. Die gebruik van hierdie strategie hou direk verband met die verskil tussen vertaling en terminologie waarna vroeër verwys is. Daar is 'n konseptuele verskil tussen tolking en verduideliking. Die woordpaar mag dalk in dieselfde konseptuele domein lê, maar tree nie as akkurate en juiste vertaalekwivalente van mekaar op nie. Die Noord-Sotho-spesialis het die probleem opgelos deur eerder 'n verinheemsde leenwoord botoloki (afgelei van die Afrikaans tolk) te gebruik. 
Die nasiener verduidelik die problematiek waarmee die aanvanklike twee vertalers te kampe gehad het aan die hand van voorbeeld 2 en 4, naamlik A-taal en aktiewe taal: die vertaalspan het die woord taal vertaal met lelema, wat 'n direkte vertaling van tong (in Afrikaans) of tongue (in Engels) is. Volgens haar is dit nie verkeerd nie, maar is polela (taal) die voorkeurvorm aangesien dit so in van die min Noord-Sotho-woordeboeke opgeneem is, naamlik dié van Kriel (1983). Hier gaan dit dus nie soseer oor 'n konseptuele probleem nie, maar oor 'n kodifiseringsen standaardiseringskwessie. Kodifisering verwys onder andere na die metodes waardeur 'n taal gestandaardiseer word. Dit sluit woordeboeke, styl- en gebruikersgidse, tradisionele grammatika en so meer in (Nordquist, 2017). Standaardisering slaag egter net indien die taalgebruikers die gekodifiseerde vorm aanvaar en die vorm inslag vind. In hierdie geval het die vertaalspan gekies om die dialektiese vorm (lelema) te gebruik. Die Noord-Sotho-spesialis het besluit om wel beide as wisselvorme aan te dui. In reaksie op die vraag oor waarom sy nie slegs die dialektiese vorm met die gekodifiseerde vorm vervang het nie, het sy geantwoord dat vertalers in Noord-Sotho hulleself die hele tyd teen kritiek moet beskerm en dat, tot tyd en wyl enige een van die twee vorme deur die taalgemeenskap as die standaardvorm erken word, dit gerade is om al twee vorme aan te dui.

Wat die vertaalstrategie betref, het die vertaalspan weer van strategie ii gebruik deurdat hulle die term tolk ('interpreter') met vertaler ('translator') vertaal het. Tolking word dikwels as 'n onderafdeling van vertaalstudies beskou (sien Pöchhacker 2004:9-13) en daarom kan hierdie strategie ook gesien word as die gebruik van 'n superordinaat as 'n spesifieke term. Die NoordSotho-spesialis het weer eerder gekies vir die gebruik van strategie iv, naamlik die gebruik van die verinheemsde leenwoord toloki.

In voorbeeld 3 (ad hoc-tolk) het die vertaalspan (soos in voorbeeld 1) strategie ii gebruik terwyl die Noord-Sotho-spesialis strategie vi, parafrasering, gebruik het. Die Latynse ad hoc is deur die vertalers as thathollo ya nakwana (tydelike verduideliking) vertaal, terwyl die NoordSotho-spesialis go toloka ka ntle go hwetša thahlo (om te vertaal sonder om opgelei te wees) voorgestel het.

Voorbeeld 4 (aktiewe taal) volg dieselfde patroon as voorbeeld 3, waar die vertaalspan strategie ii gebruik het - leleme la phetolelo (vertaaltaal) - en die Noord-Sotho-spesialis eerder parafrase voorgestel het: leleme leo toloki e kgonago go le tolokela / polelo yeo toloki e kgonago go e tolokela (taal waarin die tolk in kan tolk).

Voorbeeld 5 (antisipering) toon weer die gebruik van strategie ii deur die vertaalspan kamaka/phopholetšo (wonder/voel), terwyl die Noord-Sotho-spesialis gepaste vertaalekwivalente kemelo / letetše (antisipasie) aan die hand gedoen het.

Voorbeelde 6 en 7 A2-tolk en begripsoomblik, wat in Nederlands en Engels onderskeidelik met cheval en déclic vertaal word, het aan die vertalers wat in Afrikaans gewerk het, ook hoofbrekens besorg. In Afrikaans word die term A2-tolk as vertaalekwivalent vir cheval aangegee, met die volgende definisie: “'n Tolk wat in twee verskillende tolkhokkies geplaas kan word". Dan word begripsoomblik as Afrikaanse vertaalekwivalent vir die vreemdetaalwoord déclic voorsien, met die definisie "Oomblik in die tolkproses; die oomblik waarop dít wat in die brontaal gesê word tot die tolk deurdring en die tolk dan met die omskakeling in die doeltaal kan begin”. In die geval van voorbeeld 6 (A2-tolk) het die vertaalspan van strategie vii (weglating) gebruik gemaak mohlatholliphetelela / 
bokgoniphetelela (verduideliker/kennis), met die Noord-Sotho-spesialis wat haar eerder op parafrasering verlaat het: toloki ye e ka beiwago ka diphapošaneng tše pedi tše di fapanego tša go toloka ('n tolk wat in twee verskillende (tolk-)hokkies geplaas kan word). Wat voorbeeld 7 (begripsoomblik) betref, het die vertaalspan weereens strategie ii gebruik terwyl die NoordSotho-spesialis 'n parafrase (strategie vi) aanbeveel het.

Teen hierdie stadium is dit duidelik dat die strategie vi (parafrasering) die spesialis se voorkeurstrategie was. Dit hou onder meer verband met die redaksionele besluit, naamlik dat die artikels nie volledig in Noord-Sotho en Zulu vertaal sou word nie, maar dat slegs vertaalekwivalente aangedui sou word. Parafrase maak dit moontlik om konteks aan die gebruiker te gee en om sodoende beter betekenisleiding aan gebruikers te bied. Voorbeeld 8 (digtheid) illustreer die punt. Die vertaalspan het teteano (digtheid/bosserigheid) voorgestel. Die parafrase bokaalo bja tshedimošo bjo bo tšeiwago go seo se boletšwego (die hoeveelheid inligting van dit wat gesê word, wat geprosesseer word) is baie meer gebruikersvriendelik en betekenistoeganklik, en neem die gebruikers se kommunikasiebehoeftes in ag.

Voorbeeld 9 volg die patroon van voorbeeld 1 waar dit gaan om die konseptuele verskil tussen verduideliking en tolking of dan die gebruik van 'n meer algemene term of superordinaat.

In voorbeeld 10 gebruik die vertaalspan en die spesialis strategie iv, waar hokkie met boothi (afgelei van die Engelse booth) vertaal word. Die eerste en die finale vertaling maak ook van strategie viii (byvoeging) gebruik: Phapošanabohlathollelo / booth (verduidelikingskamer/ hokkie) en phapošana ya go toloka / boothi ya go toloka (tolkkamer of tolkhokkie).

Voorbeelde 11 en 12 toon nie die gebruik van enige nuwe strategieë nie. Dit is wel opvallend dat die finale vertalings ook hier, in teenstelling met die oorspronklike vertalings, van parafrasering as strategie gebruik maak.

In voorbeeld 13 (sluiting) kies die Noord-Sotho-spesialis egter strategie ii. Die volledige inskrywing lyk soos volg:

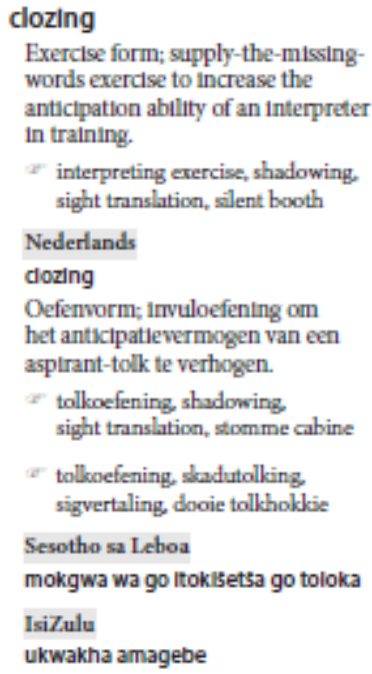

Figuur 4: Die hantering van sluiting in Tolkterminologie 
In die Afrikaanse inskrywing word daar van 'n genus-en-differentiae-definisie ${ }^{6}$ (Gouws 1989:115; Gouws en Prinsloo 2005:145; Gouws 2014:400) gebruik gemaak naamlik "vorm van oefening; invuloefening om die antisiperingsvermoë van 'n aspiranttolk te verhoog". Tolkoefening, skadutolking, sigvertaling en dooie tolkhokkie word as kruisverwysings aangegee. Dit behoort gevolglik vir die gebruikers baie duidelik te wees dat dit om 'n tipe tolkoefening gaan, want volgens Gouws (1989:115; Gouws 2014:399-401) en Gouws en Prinsloo (2005:145) word hierdie soort betekenisparafrase (die gebruik van die genus-endifferentiae-metode) - wat veral vir die verklaring van selfstandige naamwoorde se betekenis gebruik kan word - algemeen in verklarende woordeboeke gebruik, kennelik omdat hierdie definisiesoort soveel bydra tot betekenisoordrag. Die aanvanklike Noord-Sotho-span het pheleletšo ka mantšu as vertaalekwivalent aangegee, wat volgens die terugvertaling "using words for completion" geen aanduiding van die aard van die oefening gee of enigsins aandui dat dit 'n opleidingsoefening vir tolke is nie. Die nagesiene weergawe dui mokgwa wa go itokišetša go toloka (tolkoefening/“interpreting exercise”) aan - 'n superordinaat word dus ingespan.

Voorbeeld 14 (tolkhokkie-etiket) toon weer die gebruik van strategie ii waar die vertaalspan en die spesialis etiket met reëls vertaal. In voorbeeld 15 (tolkoefening) kom die diskrepansie tussen verduidelik en tolk weer aan bod.

Opvallend in voorbeeld 16 (tweerigtingtolking) en voorbeeld 17 (volgafstand) is die uitgebreide parafraserings in die finale vertaling.

Uit die voorbeelde blyk dit dat daar in die finale vertaling oorwegend van parafrasering gebruik gemaak is. Parafrasering is as die voorkeuropsie beskou aangesien dit baie moeilik was om absolute of selfs gedeeltelike vertaalekwivalente te vind. In gevalle waar die brontaalterm en die doeltaalekwivalent presies dieselfde betekenis oordra, vind ons kongruensie, wat 'n wedersydse semantiese en leksikale ekwivalensie meebring (sien Gouws 1989:164; Gouws en Prinsloo 2005: 154; Gouws 2014:402-405). Die Noord-Sotho-spesialis was van mening dat parafrase, in gevalle van zero-ekwivalensie of leksikale/linguistiese gapings waar daar 'n afwesigheid in die woordeskat van 'n spesifieke taal is (Gouws 1989:175; Gouws 2014:404), die beste opsie was en het ook gemeen dat parafrase konsepte kan oordra wat uiteindelik tot nuutskeppings aanleiding kan gee. Hieroor laat Alberts (2017:92) haarself só uit:

The terms that are coined during the developing phase of a language tend to include the definitions of the concepts behind them. Terminologists or language practitioners such as translators and interpreters also use paraphrasing to encompass the meaning of a concept. These are ways of conveying to the user the meaning attached to a term. As the terminology of a specific subject field becomes part of the language, the user will disregard the long, explanatory terms and use the shorter ones instead, the short versions becoming standardised.

In reaksie op die vraag oor waarom nuutskeppings, in die vorm van 'n enkelterm, nie in die eerste instansie as strategie aangewend is nie, het die Noord-Sotho-spesialis tereg opgemerk dat

\footnotetext{
${ }^{6}$ Hierdie soort definisies (1) onderskei die semantiese klas of die superordinaat waartoe die lemma behoort (dit is die genus) en (2) lys 'n aantal spesifieke kenmerke (die verskille) wat die lemma van ander lede van hierdie klas onderskei (die differentiae).
} 
alhoewel nuutskeppings dié voordeel het dat dit bondig kan wees (in teenstelling met parafrasering) dit ook niksseggend kan wees sonder die nodige konteks en bykomende inligting.

\section{Gevolgtrekkings}

Sover is daar geargumenteer dat tolkterminologie nog nie in alle Suid-Afrikaanse tale gestandaardiseer is nie en dat Salaets, Segers en Bloemen se 2008-werk, Terminologie van het tolken”, gevolglik in Afrikaans en Engels vertaal is en vertaalekwivalente in Noord-Sotho en Zulu bygevoeg is in 'n poging om hierdie leemte te vul.

Die samestellers het egter nie volledig rekening gehou met die impak van die besluit om NoordSotho-vertaalekewivalente by te voeg nie. Aangesien Noord-Sotho nog nie ten volle gestandaardiseer is nie, moes die Noord-Sotho-vertalers ook as terminoloë optree. Vertaling en terminologie is egter verskillende dissiplines waar die vertaler besig is met die manipulering van tekste en die terminoloog met abstrakte kognitiewe eenhede werk.

Die vakgerigte benadering tot terminografie is gevolg. Dit het egter gou geblyk dat die aard van die projek aanpassing van die stappe wat hierdie benadering kenmerk, sou vereis. Nederlands was die brontaal. Afrikaans was die eerste doeltaal. Die lemmalys is gelokaliseer vir SuidAfrikaanse omstandighede; lemmas is bygevoeg of weggelaat. Die Engelse vertaling is uit die Afrikaans gedoen waarna die oorspronklike Nederlandse lys aangepas is om dit in ooreenstemming met die Afrikaanse en Engelse lys en inhoud te bring. Eers op hierdie stadium is die Zulu- en Noord-Sotho-vertaalekwivalente bygevoeg.

Nadat die Noord-Sotho-vertaalspan hulle werk afgehandel het, het die vermoede ontstaan dat die aanvanklike vertalings nie sonder meer aanvaar kon word nie. Die hulp van twee nasieners is ingeroep. Dit is belangrik om ook hier te meld dat die twee vertalers en die twee nasieners, benewens hulle taal- en vertaalkennis, ook praktiserende tolke is en dus vertroud is met tolkpraktyk. Steeds kon hulle nie ooreenstemming bereik oor aanvaarbare vertaalekwivalente nie. Aangesien die samestellers van Tolketerminologie nie Noord-Sotho magtig is nie is daar, ter wille van gehaltebeheer, van terugvertalings in Engels gebruik gemaak ten einde te verseker dat die vertaalekwivalente wel die korrekte en bedoelde boodskap oordra en dat elke term 'n korrekte linguistiese voorstelling van elke konsep is. Op grond van die eerste stel terugvertalings, is 'n Noord-Sotho-spesialis aangestel om verdere voorstelle te maak.

Hierdie probleme is nie uniek aan hierdie projek of aan die tale wat hier ter sprake is nie. Alberts (2017:90) wys daarop dat "[...] term equivalents may denote the concepts exactly (full equivalence) or in some cases it might not be possible to denote the concept in certain languages since only partial relationships exist (partial equivalence). In some cases there is no relationship (zero equivalence) at all between the SL and TL terms.” Daar sal altyd waarneembare verskille tussen die terminologieë van verskillende tale wees (Alberts 2017:91).

Dit was 'n besondere sinvolle proses omdat die tipe probleme waarvoor die vertalers te staan gekom het asook hulle strategieë om dilemmas op te los, duidelik sigbaar was (sien kolom 2 van tabel 1 hierbo).

Op versoek van die samestellers, het die Noord-Sotho-spesialis ook terugvertalings voorsien. Die twee stelle terugvertaling asook gesprekke met die vertalers en 'n formele onderhoud met 
die spesialis het verskeie insigte gebring, waaronder en veral die geweldige kompleksiteite wat daaraan verbonde is om vakterminologie te vertaal in 'n taal wat nog nie volledig gestandaardiseer is nie. Die samestellers het 'n groter begrip ontwikkel vir die gebruik van verskillende vertaalstrategieë soos die gebruik van superordinate, parafrasering, (wat lompheid tot gevolg het omdat 'n enkele term nie voorsien word nie), leenwoorde en selfs onakkurate vertalings. Wat staan vertalers immers te doen as hulle met 'n taal werk waar kodifiseringspogings in woordeboeke nog nie algemeen inslag gevind het nie?

Waar die Afrikaanse vertalers met nuutskeppings kon werk omdat die definisie en kruisverwysings konteks kon gee, kon dit nie so plaasvind in die Noord-Sotho nie, omdat die aard van die opdrag nie voorsiening gemaak het vir die volledige vertaling van die volledige woordeboekartikel nie. Alberts (2017: 106) waarsku hieroor:

By supplying term equivalents only in a developing language, the terminologist does not really help the user to retrieve or use dictionary information. In the case of developing languages, a terminologist should rather supply definitions, explanations and usage examples in the TLs. The L1 speaker will then be able to access and retrieve information on a concept and will be able to put concept, definition and SL into perspective. The L1 equivalent may, for instance, exist in the language, and when the user can put source term and concept into a logical pattern or classification system, they should be able to obtain the relevant term equivalent.

Die voorgestelde nuutskeppings in Noord-Sotho was in vele gevalle problematies, soos reeds aangedui. Die samestellers wou verhoed dat onakkurate nuutskeppings as terme in die eindproduk opgeneem word. Daar is dus in sommige gevalle, gegee die gebrek aan kontekstuele inligting (soos definisies), eerder van parafrasering as van bedenklike nuutskeppings gebruik gemaak.

By nabaat erken die samestellers dat die beperking leksikografiese hantering in Noord-Sotho en Zulu nie optimaal is nie, maar hierdie besluit is geneem in die lig van befondsingsgebreke. Befondsing is bekom vir die vertaling en lokalisering van die teks in Afrikaans. Omdat die samestellers Engels en Nederlands magtig is en iets van die Suid-Afrikaanse omstandighede aan hulle Lae Landse-eweknieë wou teruggee, het die proses in dié drie tale redelik glad verloop. In reaksie op die standpunt (sien afdeling 2 hierbo) dat daar 'n gebrek aan gestandaardiseerde tolkterminologie in die Afrikatale is, het die begeerte by die projekleiers ontstaan om wel ook 'n bydrae te maak wat betref tolkterminologie in Noord-Sotho en Zulu. Die proses was egter veel meer kompleks as wat aanvanklik voorsien is en die standaardiseringsgebreke het aanleiding gegee tot veelvuldige hersieningsprosesse wat uiteraard daartoe aanleiding gegee het dat uitgawes verhoog het. Dan waag die samestellers, gegee die relatiewe gebrek aan probleme tydens die voorsiening van vertaalekwivalente in Zulu, teenoor die magdom probleme wat met die Noord-Sotho-proses ondervind is, die hoogs aanvegbare stelling dat Zulu verder op die pad van standaardisering as Noord-Sotho is. Gevolglik was daar meer uitgawes verbonde aan die Noord-Sotho-gedeelte van die projek as die Zulu.

Uiteindelik word die hoop uitgespreek dat Tolkterminologie en hierdie artikel 'n bydrae sal lewer tot die standaardisering van tolkterminologie in Noord-Sotho (en uiteraard Zulu ook) en dat diegene wat die aflosstokkie by ons oorneem hierby sal baat. Die taalbeplanningsgerigte 
benadering tot terminografie in Noord-Sotho, die taak wat PanSAT en in die konteks van hierdie artikel dan spesifiek die Nasionale Taalliggaam vir Noord-Sotho opgelê is, moet dringend voorkeur geniet; daarsonder sal die standaardisering van Noord-Sotho, en ander inheemse tale, veel langer sloer tot nadeel van diegene wat presies en duidelik wil kommunikeer, veral op tegniese en spesialiskennisdomeine.

\section{Verwysings}

Alberts, M. 2017. Terminology and terminography: principles and practice. Milnerton: McGillivray Linnegar Associates Publishers.

Anyele, S.Q. 2015. Source Language Delivery Speed and Simultaneous Interpreters' Strategies at the Pan-African Parliament. Ongepubliseerde MA-verhandeling. Universiteit van Johannesburg.

Baker, M. (red.) 2001. Routledge Encyclopedia of Translation Studies. London: Routledge.

Baker, M. 2011. In other words. A coursebook in translation. $2^{\text {nd }}$ edition. London: Routledge. https://doi.org/10.4324/9780203832929

Bothma, R. en M. Verhoef. 2008. Assessing the role of the interpreter in facilitating classroom communication. In M. Verhoef, en T. Du Plessis (reds). Multilingualism and educational interpreting: Innovation and delivery. Pretoria: Van Schaik.

Brewis, C. 2012. Die bevorderlikheid van opvoedkundige tolking vir effektiewe onderrig en leer binne die konteks van die Fakulteit Regsgeleerdheid aan die Universiteit van Stellenbosch. Ongepubliseerde MA-verhandeling. Universiteit Stellenbosch.

Brewis, C. 2014. Die waarde van tolking vir tersiêre onderrig en leer. 'n Ondersoek na die persepsies van tolkgemedieerde kommunikasie in die Fakulteit Regsgeleerdheid aan die Universiteit van Stellenbosch. Stellenbosch Papers in Linguistics Plus 45: 43-70. https://doi.org/10.5842/45-0-206

Cabré, M.T. 2010. Terminology and translation. In L. van Doorslaer en Y. Gambier (reds.). Handbook of translation studies. Volume 1. Amsterdam/Philadelphia: John Benjamins Publishing Company. https://doi.org/10.1075/hts.1.ter1

Chesterman, A. 1997. Memes of translation: The spread of ideas in translation theory. Amsterdam/Philadelphia: John Benjamins Publishing Company. https://doi.org/10.1075/btl.22

Clausen, M. 2011. Die potensiaal van tolking in die Fakulteit Lettere en Sosiale Wetenskappe (US): Die Departement Maatskaplike Werk as gevallestudie. Ongepubliseerde MAverhandeling. Universiteit Stellenbosch.

Cornelius, E. en M. Pienaar. 2017. Die vertaling en lokalisering van Terminologie van het Tolken vir 'n Suid-Afrikaanse teiekengehoor. Stellenbosch Papers in Linguistics Plus 47: 181201 
Dose, S. 2010. Patterns of growing standardization and interference in interpreted German discourse. Ongepubliseerde MA-verhandeling. Universiteit van Suid-Afrika.

Du Plessis, M. 2017. Church interpreting in an interdenominational Christian context in urban Johannesburg. Ongepubliseerde MA-verhandeling. Universiteit van die Witwatersrand.

Feinauer, I. en H.M. Lesch. 2013. Health workers: idealistic expectations versus interpreters' competence. Perspectives: Studies in Translatology 21(1): 117-132. https://doi.org/10.1080/ $\underline{0907676 X .2011 .634013}$

Gouws, R.H. 1989. Leksikografie. Pretoria: Academica.

Gouws, R.H. 2014. Leksikografie. In: W.A.M. Carstens en N. Bosman (reds). Kontemporêre Afrikaanse Taalkunde. Pretoria: Van Schaik.

Gouws, R.H. en D.J. Prinsloo. 2005. Principles and practice of South African lexicography. Stellenbosch: Sun Press.

Kriel, T.J. 1983. Pukuntšu Woordeboek. Noord-Sotho-Afrikaans - Noord-Sotho. Pretoria: Van Schaik.

Le Roux, M. 2007. Die rol van die opvoedkundige tolk in 'n tersiere klaskamer. Ongepubliseerde MA-verhandeling. Universiteit van Johannesburg.

Lesch, H. 2010. A descriptive overview of the interpreting service in Parliament. Acta Varia 42(3): 38-60.

Lesch, H. 2014. Die waarde en uitdagings van diensleer vir tolkopleiding: die ervaring van die tolkopleidingsprogram aan die Universiteit van Stellenbosch. Stellenbosch Papers in Linguistics 43: 209-233. https://doi.org/10.5842/43-0-201

Makhubu, R.L. 2011. Development of an interpreting service model at the Durban University of Technology. Ongepubliseerde doktorale verhandeling. Durban Universiteit van Tegnologie.

Mathey, G. 2017. Using technology to pre-assess candidate interpreters. Ongepubliseerde MAverhandeling. Universiteit van die Witwatersrand.

Molefe, M.A. 2015. Interpreting and translation for service delivery in local public contexts. Ongepubliseerde MA-verhandeling. Universiteit van die Vrystaat.

Moropa, K. 2008. A parallel corpus as a terminology resource for Xhosa: A study of strategies used to translate financial statements. Language Matters 35(1): 162-178. https://doi.org/10. $\underline{1080 / 10228190408566210}$

Ndlovu, V. 2006. The limits of simplification in translated isiZulu health texts. South African Journal of African Languages 3: 121-130. https://doi.org/10.1080/02572117.2006.10587275 
Ngobeni, M.M. 2013. An analysis of zero equivalence in the translation of scientific terms from English into Northern Sotho. Ongepubliseerde MA-verhandeling. Universiteit van Limpopo.

Nordquist, R. 2017. Glossary of Grammatical and Rhetorical Terms. Aanlyn beskikbaar www.thoughtco.com. (Toegang gekry 5 April 2018)

Olivier, H. 2008. Process, product and performance: Differences between conference interpreters and educational interpreters. In: M. Verhoef en T. du Plessis (eds.), Multilingualism and educational interpreting: Innovation and delivery. Pretoria: Van Schaik.

Ouane, A. en C. Glanz. 2010. Why and how Africa should invest in African languages and multilingual education. An evidence- and practice-based policy advocacy brief. Hamburg: UNESCO Institute for Lifelong Learning.

Pienaar, M. en E. Cornelius. 2015. Contemporary perceptions of interpreting in South Africa. Nordic Journal for African Studies 24(2): 186-206.

Pienaar, M. en E. Cornelius. 2018. Interpreting terminology / Terminologie van het tolken / Tolkterminologie / Mareo a botoloki /Amatemu okutolika. Stellenbosch: Sun Media. https://doi.org/10.18820/9781928314417

Pöchhacker, F. 2004. Introducing interpreting studies. London: Routledge. https://doi.org/10. $\underline{4324 / 9780203504802}$

Prah, K.K. 2007. Challenges to the promotion of indigenous languages in South Africa. Cape Town: CASAS.

Ralarala, M.K. 2012. A compromise of rights, rights of language and rights to a language in Eugene TerreBlanché's (ET) trial within a trial: evidence lost in translation. Stellenbosch Papers in Linguistics 41: 55-70. https://doi.org/10.5774/41-0-43

Ralarala, M.K. 2014. Transpreters' translations of complainants' narratives as evidence: whose version goes to court? The Translator 29 July: 1-19. https://doi.org/10.1080/13556509. $\underline{2014.934002}$

Sager, J.C. 2001. Terminology. In M. Baker (red.) Routledge Encyclopedia of Translation Studies. London: Routledge.

Salaets, H., W. Segers, en H. Bloemen. 2008. Terminologie van het tolken. Vantilt: Nijmegen.

Saulse, B. 2010. Interpreting within the Western Cape health care sector: a descriptive overview. Ongepubliseerde MPhil-verhandeling. Universiteit Stellenbosch.

Sibula, P.M. 2007. Furthering the aim of multilingualism through integrated terminology development. Lexikos 17: 397-406. 
Taljard, E. 2008. Terminology Practice in a Non-standardized Environment: A Case Study. In E. Bernal en J. de Cesaris (reds.) Proceedings of the XIII Euralex International Congress. 1519 Julie 2008. Barcelona: Universitat Pompeu Fabra. bl. 1073-1080.

Verhoef, M. 2008. Accounting for paralanguage and non-verbal communication in the educational interpreting service rendered at the North-West University. In M. Verhoef en T. du Plessis (reds.) Multilingualism and educational interpreting: Innovation and delivery. Pretoria: Van Schaik.

Verhoef, M. 2010. Taalbeleid en onderrigtaalmodus aan die Noordwes-Universiteit. Panorama: FW de Klerk Stigting. bl. 168-184.

Verhoef, M. en T. Du Plessis (reds.). 2008. Multilingualism and educational interpreting: Innovation and delivery. Pretoria: Van Schaik.

Verhoef, M. en J. Blaauw. 2009. Towards comprehending spoken-language educational interpreting as rendered at a South African University. In J. Inggs en L. Meintjies (reds.). Translation Studies in Africa. London \& New York: Continuum.

Wallmach, K. en A. Kruger. 1999. 'Putting a sock on it': a contrastive analysis of problemsolving translation strategies between African and European languages. South African Journal of African Languages 19(4): 276-289. https://doi.org/10.1080/02572117.1999.10587406

Wallmach, K. en A. Kruger. 2010. Translating and editing techniques. Study guide for LIN304A. University of South Africa.

Wittezaële, O.L. 2008. The relationship between interpreters and users of the interpreting services at the Potchefstroom campus of the North-West University. Ongepubliseerde DPhilverhandeling. Noord-Wes Universiteit. 